\title{
ANALISIS EFISIENSI TEKNIS USAHA BUDIDAYA PEMBESARAN IKAN KERAPU DALAM KERAMBA JARING APUNG DI TELUK LAMPUNG
}

\section{ANALYSIS OF TECHNICAL EFFICIENCY OF GROUPER GROWTH OUT IN FLOATING NET CAGES IN LAMPUNG BAY}

\author{
Tajerin $^{\star}$
}

\begin{abstract}
Level of technical efficiency in fish culture reflecting the fish farmers achievement correlated to their managerial competency to manage the principle factors affecting its productivity. Objectives of this research were to evaluate technical efficiency in grouper growth out as well as its policy implication. This research was conducted in Lampung Province during September to December 2002. The area was selected by purposive sampling in Padang Cermin Sub district, South Lampung, and the respondent of farmers were selected by census method. The results showed that the average of technical efficiency level achieved by grouper farmers in floating net cages should be classified in middle to high categories with relatively homogen distribution. Principle factors affecting the technical efficiency was level of income from farming fish culture. As the technical efficiency level closed to the frontier, policy of culture development should be conducted using area-based extensive culture approach and should applicate imperative and innovative technologies.
\end{abstract}

\section{Keywords: Frontier production, floating net cage, grouper, technical efficiency}

\section{Pengantar}

Dalam kegiatan produksi, tujuan pembudidaya ikan adalah memaksimumkan keuntungan usaha. Perolehan keuntungan maksimum berkaitan erat dengan efisiensi dalam berproduksi. Proses produksi yang tidak efisien dapat disebabkan oleh dua hal berikut. Pertama, karena secara teknis tidak efisien. Ini terjadi karena ketidakberhasilan mewujudkan produktivitas maksimal; artinya per unit paket masukan (input bundle) tidak dapat menghasilkan produksi maksimal. Kedua, secara alokatif tidak efisien karena pada tingkat harga-harga masukan (input) dan keluaran (output) tertentu, proporsi penggunaan masukan tidak optimum. Ini terjadi karena produk penerimaan marjinal (marginal revenue product) tidak sama dengan biaya marjinal (marginal cost) masukan (input) yang digunakan.

Secara empiris hampir semua pembudidaya ikan adalah sebagai penerima harga (price taker) dalam pasar masukan (input) maupun keluaran (output) karena sangat jarang dijumpai sekumpulan pembudidaya ikan mampu mengorganisir kelompoknya sehingga mempunyai posisi tawar (bargaining position) yang kuat di pasar. Dengan latar belakang seperti itu, dalam praktek sehari-hari orientasi para pembudidaya ikan dalam suatu komunitas dan ekosistem yang relatif homogen cenderung mengejar efisiensi teknis yang dalam kehidupan sehari-hari diterjemahkan sebagai upaya memaksimalkan produktivitas.

Mengkaji persoalan tentang produktivitas sebenarnya adalah mengkaji masalah efisiensi teknis karena ukuran produktivitas pada hakekatnya menunjukkan pada seberapa besar keluaran (output) dapat dihasilkan per unit masukan (input) tertentu. Jika faktor harga diasumsikan given, efisiensi teknis pada akhirnya menentukan pendapatan yang diterima pembudidaya ikan.

Dalam kenyataannya, pembudidaya ikan tidak selalu dapat mencapai tingkat efisiensi teknis seperti yang diharapkan.

\footnotetext{
'Pusat Riset Pengolahan Produk dan Sosial Ekonomi Kelautan dan Perikanan, Departemen Kelautan dan Perikanan, JI. K.S. Tubun Petamburan VI PO BOX 6650, Slipi, Jakarta E-mail : prppse@cbn.net.id
} 
Meskipun mempergunakan paket teknologi yang sama, pada musim yang sama dan di areal yang sama, keragaman selalu muncul. Hal ini disebabkan keluaran (output) yang dicapai pada dasarnya merupakan resultante dari bekerjanya banyak faktor, baik yang tidak dapat dikendalikan (external factors) maupun yang dapat dikendalikan (internal factors). Oleh karena di luar kendali pembudidaya ikan maka perilaku faktor eksternal dianggap given. Sebenarnya jika dipilih lebih lanjut terdapat dua kategori faktor eksternal, yaitu: (a) "strictly external" karena mutlak berada di luar kendali pembudidaya ikan (seperti iklim, bencana alam) dan (b) "quasi external" karena dengan suatu aksi kolektif, intens dan waktu yang cukup (dengan dibantu pihakpihak yang kompeten) pembudidaya ikan mempunyai kesempatan untuk mengubahnya (seperti harga, infrastruktur dan sebagainya). Faktor-faktor internal lazimnya berkaitan erat dengan kapabilitas manajerialnya dalam berusaha. Tercakup dalam gugus faktor ini adalah tingkat penguasaan teknologi budidaya dan pasca panen serta kemampuan pembudidaya ikan mengakumulasikan dan mengolah informasi yang relevan dengan usaha budidayanya sehingga pengambilan keputusan yang dilakukan menjadi tepat.

Wujud kapabilitas manajerial dalam aspek budidaya ikan tercermin dalam aplikasi teknologi usaha bidudaya tersebut. Masukan apa saja yang digunakan, berapa banyak, kapan (berapa kali) dan dengan cara bagaimana mengaplikasikannya merupakan unsur-unsur pokok yang tercakup dalam aplikasi teknologi tersebut. Pada akhirnya, kapabilitas manajerial akan tercermin dari keluaran (output) yang diperolehnya. Jika produksi yang diperoleh mendekati potensi maksimum dari suatu aplikasi teknologi yang terbaik (the best practiced) di suatu ekosistem yang serupa, maka dapat dikatakan bahwa pembudidaya ikan tersebut telah mengelola usaha budidayanya dengan tingkat efisiensi teknis yang tinggi.
Usaha budidaya ikan kerapu dengan sistem karamba jaring apung di Propinsi Lampung berkembang pesat, hal ini didukung oleh potensi sumberdaya tersedia cukup besar, orientasi pasar ekspor dengan harga yang tergolong tinggi. $\mathrm{Di}$ samping itu didukung pula dengan telah dikuasainya teknologi dalam usaha budidaya ikan kerapu mulai dari teknologi pembenihan, pendederan hingga pembesaran (Akbar, 2001).

Pengembangan usaha budidaya ikan kerapu dalam keramba jaring apung juga perlu memperhatikan kondisi tingkat efisiensi teknis. Efisiensi teknis adalah suatu ukuran relatif dan sesungguhnya abstrak. Dalam praktek keseharian, secara individual seorang produsen hanya akan menyadari hakekat efisiensi teknis hanya jika inefisiensi (inefficiency) yang dialaminya secara nyata mengakibatkan kerugian yang terukur. Di sisi lain, secara agregat berlangsungnya inefisiensi (inefficiency) dalam waktu yang cukup panjang jelas akan sangat merugikan karena secara sosial terjadi pemborosan sumberdaya yang semakin langka seiring dengan meningkatnya kebutuhan dan adanya proses degradasi. Dengan mengetahui kondisi tingkat efisiensi teknis usaha, pengusaha dapat mempertimbangkan perlu tidaknya suatu usaha dikembangkan lebih lanjut dan dengan pendekatan bagaimana bila memang pengembangan usaha tersebut diperlukan (Jondrow et al., 1982).

Untuk kasus usaha budidaya ikan kerapu dalam keramba jaring apung di Propinsi Lampung, penentuan kondisi tingkat efisiensi teknis dipandang perlu karena berkaitan dengan strategi pengembangan sistem usaha dan peningkatan produktivitas budidaya kerapu ke depan, apakah sebaiknya mengarah pada penerapan sistem intensifikasi atau ekstensifikasi. Untuk itu, perlu dilakukan analisis efisiensi teknis usaha budidaya ikan kerapu dalam keramba jaring apung di Propinsi Lampung. 
Penelitian ini bertujuan: (a) untuk mengetahui tingkat efisiensi teknis yang dicapai pembudidaya ikan dalam menjalankan usaha budidayanya, (b) bagaimana sebaran efisien teknis tersebut diantara pembudidaya pembesaran ikan kerapu dan (c) faktor-faktor apa yang mempengaruhi kapabilitas manajerial sebagaimana tercermin dari tingkat efisiensi teknis yang dicapai.

Hasil penelitian ini diharapkan akan berguna bagi pengambilan keputusan dalam merumuskan strategi kebijakan pengembangan budidaya ikan kerapu dengan sasaran meningkatkan efisiensi dan produksi, khususnya dalam konteks berikut. Pertama, jika tingkat efisiensi teknis yang dicapai telah sangat tinggi (mendekati frointer) berarti peluang untuk meningkatkan lebih lanjut menjadi tidak optimistik sehingga kebijakan yang ditempuh haruslah mencari alternatif lain (misalnya mempercepat perluasan areal keramba jaring apung baru). Sebaliknya jika masih cukup rendah berarti masih cukup besar peluang untuk meningkatkannya dengan teknologi yang telah ada. Dalam konteks ini maka kelompok sasarannya adalah pembudidaya ikan yang efisiensi teknisnya masih rendah. Kedua, faktor-faktor apa yang menjadi determinan dalam manajemen usaha budidaya pembesaran ikan kerapu dalam keramba jaring apung, dan apakah upaya mengurangi faktor-faktor yang berpengaruh negatif dan atau meningkatkan faktorfaktor yang berpengaruh positif dapat atau layak dilakukan?.

\section{Bahan dan Metode}

\section{Spesifikasi model}

Salah satu metoda estimasi tingkat efisiensi teknis yang banyak digunakan adalah melalui pendekatan Stochastic Production Frointer (SPF). Metoda ini pertama kali diperkenalkan oleh Aigner et al., (1977); dan dalam saat yang bersamaan juga dilakukan oleh Meeusen and Broek (1977). Pengembangan pada tahun-tahun berikutnya banyak dilakukan seperti oleh Battase and Coelli (1988, 1992, 1995), Waldman (1984), Kumbhakar (1987) maupun Greene (1993). Pendekatan SPF juga pernah digunakan misalnya Erwidodo $\left(1992^{\mathrm{a}}\right.$ dan 1992 ${ }^{b}$ ) maupun Siregar (1987). Dalam penelitian ini digunakan model SPF yang telah mengalami pengembangan lebih lanjut, yaitu model Stochastic Production Frointer - Technical Efficiency (SPF-TE) Effect Model sebagaimana dilakukan oleh Battesa and Coelli (1995) maupun Yao and Liu (1998). Model tersebut relatif lebih baik dari yang digunakan dalam penelitian-penelitian terdahulu. Hal ini karena dalam model penelitian ini parameter yang bekerja dalam proses produksi dan parameter yang mencerminkan kapabilitas manajerial usaha budidaya diestimasi secara simultan agar konsisten (Kumbhakar, 1987).

Bentuk umum dari SPF-TE Effect Model dapat dipresentasikan sebagai berikut:

$Y_{i t}=X_{i t} \beta+\left(V_{i t}-V_{i t}\right) ; \quad$ (1)

$\mathrm{i}=1, \ldots, \mathrm{N}$ dan

$\mathrm{t}=1, \ldots, \mathrm{T}$.

dimana:

$Y_{\text {it }}$ : produksi yang dihasilkan pembudidaya ikan-i pada waktu-t

$\mathrm{X}_{\text {it }}$ : vektor masukan (input) yang digunakan pembudidaya ikan-i pada waktu-t

$\beta$ : $\quad$ vektor parameter yang diestimasi

$\mathrm{V}_{\text {it }}$ : variabel acak berkaitan dengan faktor-faktor eksternal dan sebarannya normal $\left(V_{i t} \approx N\left(0, \sigma_{v}^{2}\right)\right.$.

$\mathrm{U}_{\text {it }}$ : variabel acak non negatif, dan diasumsikan mempengaruhi tingkat inefisiensi teknis dan berkaitan dengan factor-faktor internal. Sebaran $U_{i t}$ bersifat "truncated" $\left(\left(U_{i t} \approx\left(m_{i t}, \sigma_{u}^{2}\right) ; m_{i t}=z_{i t} \delta\right)\right)$.

$Z_{\text {it }}$ : suatu vektor $(\mathrm{p} \times 1)$ variabelvariabel yang mempengaruhi efisiensi teknis usaha budidaya (karena faktor manajerial)

$\delta: \quad$ vektor $(1 \times \mathrm{p})$ parameter yang akan diestimasi. 
Seperti halnya dalam SPF yang diintroduksi oleh Aigner et al., (1977) mendefinisikan bahwa $U_{\text {it }}$ merupakan komponen specific error term $\left(\varepsilon_{i \mathrm{it}}\right)$ yakni $\varepsilon_{\mathrm{it}}=\mathrm{v}_{\mathrm{it}}-\mathrm{u}_{\mathrm{it}}$. Bentuk umum dari ukuran efisiensi teknis yang dicapai oleh observasi ke-i pada waktu ke-t didefinisikan sebagai berikut (Coelli, 1996):

$$
\begin{aligned}
& T E_{i t}=E\left(Y_{i t}^{*} \mid\left(U_{i t}, X_{i t}\right) / E\left(Y_{i t}^{*} \mid U_{i t}=0, X_{i t}\right)\right. \\
& T E_{i t}=\exp \left(-E\left[u_{i t} ; \in_{i t}\right]\right)
\end{aligned}
$$

dan ukuran efisiensi teknis individual petani dapat dihitung dari nilai harapan $\mathrm{u}_{\mathrm{it}}$ dengan syarat $\varepsilon_{\text {it }}$ sebagai berikut (Jondrow et al., 1982):

$E\left[u_{i} ; \in_{i}\right]=\frac{\sigma_{u} \sigma_{v}}{\sigma}\left[\frac{f\left(\in_{i} \lambda / \sigma\right)}{1-F\left(\in_{i} \lambda / \sigma\right)}-\frac{\epsilon_{i} \lambda}{\sigma}\right]$ (4)

dimana $f(\varepsilon, \lambda / \sigma)$ dan $F(\varepsilon, \lambda / \sigma)$ masingmasing merupakan fungsi densitas standar normal dan fungsi distribusi standar normal. Oleh karena $\left(U_{i t} \approx\left(m_{i t}, \sigma_{u}^{2}\right)\right.$ dan non negatif maka besaran SPF-TE berada pada selang $0-1$ atau $0 \leq \mathrm{TE}_{\mathrm{it}} \leq 1$.

Sebagaimana lazimnya dalam fungsi produksi, faktor-faktor yang secara langsung mempengaruhi kuantitas produk yang dihasilkan adalah faktor-faktor produksi yang digunakan. Faktor-faktor tersebut adalah luasan keramba, benih ikan, pakan ikan dan tenaga kerja manusia. Selain faktor-faktor yang sifatnya langsung tersebut, ada pula yang sifatnya tidak langsung. Faktor-faktor ini berkaitan erat dengan kiat-kiat manajemen dalam usaha budidaya pembesaran ikan kerapu dalam keramba jaring apung. Sebagaimana dijelaskan sebelumnya, dalam tataran praktis upaya maksimasi keuntungan biasanya diwujudkan melalui peningkatan efisiensi teknis. Berdasarkan pengamatan empiris, faktor-faktor tersebut berkaitan erat dengan karakteristik pembudidaya ikan kerapu seperti umur, pendidikan dan status ekonomi. Dengan demikian model yang digunakan dalam penelitian ini sebagai berikut:

$$
\begin{aligned}
& \ln y_{i t}=\ln \beta_{0}+\sum_{k=1}^{4} \beta_{k} \ln x_{k i}+\phi D_{1}+V_{i}-U_{i} \\
& V_{i} \approx N\left(0, \sigma_{v}^{2}\right) \quad \text { (5) } \\
& \left|U_{i}\right|=\delta_{0}+\sum_{l=1}^{3} \delta_{l} z_{l i}+\rho D_{2}+\vartheta D_{3}{ }^{(6)}
\end{aligned}
$$

dimana:

(a) Variabel-variabel yang bekerja dalam fungsi produksi,

$y_{\text {it }} \quad$ : Jumlah produksi ikan kerapu $(\mathrm{kg})$

$\mathrm{x}_{1}$ : luas area keramba jaring apung $\left(\mathrm{m}^{2}\right)$

$x_{2}$ : jumlah benih ikan kerapu $(\mathrm{kg})$

$x_{3}$ : jumlah pakan ikan kerapu $(\mathrm{kg})$

$\mathrm{x}_{4}$ : jumlah tenaga kerja manusia (jam kerja setara pria)

(b) Variabel-variabel yang mempengaruhi ketidakefisienan (inefficiency),

$\mathrm{z}_{1}$ : jumlah pendapatan per kapita (juta rupiah)

$\mathrm{z}_{2}$ : tingkat pangsa pendapatan keluarga dari usaha budidaya ikan terhadap total pendapatan keluarga (\%).

$\mathrm{z}_{3}$ : tingkat umur pembudidaya ikan (tahun)

$\mathrm{z}_{4}$ : tingkat pendidikan formal pembudidaya ikan (tahun)

$\mathrm{z}_{5}$ : lama mengikuti pelatihan budidaya ikan kerapu (jam)

$\mathrm{D}_{1}$ : variabel dummy lokasi dalam hamparan dekat pantai $=1$, lainnya $=0$

$\mathrm{D}_{2}$ : variabel dummy lokasi terpencar di pulau-pulau kecil $=1$, lainnya $=0$

Pendugaan parameter yang tak bias adalah menggunakan metoda Maximum Likelihood (MLE). Agar konsisten maka pendugaan parameter fungsi produksi dan inefficiency dilakukan secara simultan dengan program FROINTER Version 4.1 (Coelli, 1996) dengan opsi Technical Efficiency Effect Model.

\section{Lokasi penelitian dan pengumpulan data}

Penelitian ini merupakan kajian yang dilakukan dengan menggunakan kasus pada usaha budidaya pembesaran ikan 
kerapu di Perairan Teluk Lampung. Penelitian dilakukan sejak September hingga Desember 2002. Sampai dengan saat dilakukan penelitian ini, kegiatan budidaya pembesaran ikan kerapu dalam keramba jaring apung di Propinsi Lampung masih terkonsentrasi di areal sekitar Perairan Teluk Lampung yang secara administratif temasuk dalam Kecamatan Padang Cermin, Kabupaten Lampung Selatan. Selain itu, dengan pertimbangan bahwa di lokasi tersebut adalah satu-satunya sentra produksi kegiatan budidaya ikan kerapu dalam keramba jaring apung di Propinsi Lampung, maka dalam penelitian ini secara sengaja (purposive) lokasi tersebut ditentukan sebagai wilayah sampel. Populasi pembudidaya ikan di wilayah sampel tersebut sebanyak 34 orang petani, sehingga untuk pengumpulan data digunakan metoda sensus diambil dari semua petani pembudidaya ikan kerapu tersebut.

\section{Hasil dan Pembahasan}

Hasil estimasi parameter SPF-TE effect model

\section{Fungsi produksi}

Hasil estimasi SPF (Stochastic Production Frointer) versi TE (Technical Efficiency) Effect Model dijabarkan pada Tabel 1. Hasil analisis mendapatkan bahwa $\gamma=$ 0,84 dan nyata secara statistik pada $\alpha=0,01$. Hal ini mencerminkan random errors yang tidak dapat diterangkan dalam model fungsi produksi sangat dominan; dan inilah yang diterangkan dalam "Inefficiency Function". Dalam fungsi produksi faktor-faktor yang berpengaruh nyata dengan arah positif adalah tingkat luasan areal keramba jaring apung dan pakan ikan; sedangkan yang berpengaruh nyata namun dengan arah negatif adalah benih ikan. Tenaga kerja manusia baik untuk aktivitas pemeliharaan maupun panen meskipun berpengaruh positif tetapi tidak nyata.

Tabel 1. Estimasi parameter SPF versi TE effect model pada usaha budidaya pembesaran ikan kerapu dalam keramba jaring apung di propinsi Lampung.

\begin{tabular}{|c|c|c|}
\hline Parameter & Koefisien & t-hitung \\
\hline \multicolumn{3}{|l|}{ Fungsi Produksi } \\
\hline Intersep & 2,2631 & 19,0246 \\
\hline$x_{1}$ Luas Areal Keramba Jaring Apung & $0,4479^{*}$ & 15,6238 \\
\hline $\mathrm{x}_{2}$ Benih Ikan & $0,2261^{*}$ & 2,1898 \\
\hline$x_{3}$ Pakan Ikan & $0,6253^{*}$ & 2,8911 \\
\hline $\mathrm{x}_{4}$ Tenaga Kerja Manusia & 0,0543 & 1,6783 \\
\hline \multicolumn{3}{|l|}{ Fungsi "U" } \\
\hline Intersep & 0,5957 & 5,9824 \\
\hline $\mathrm{z}_{1}$ Pendapatan Per Kapita & $-0,0736^{*}$ & $-4,1196$ \\
\hline $\mathrm{z}_{2}$ Pangsa Pendapatan Usaha Budidaya Ikan Kerapu & $-0,4964^{*}$ & $-6,9533$ \\
\hline $\mathrm{z}_{3}$ Umur & $-0,0731^{*}$ & $-3,2196$ \\
\hline $\mathrm{Z}_{4}$ Pendidikan Formal & $-0,0046$ & $-0,6315$ \\
\hline $\mathrm{z}_{5}$ Pelatihan Budidaya Ikan Kerapu & $-0,2118^{\star}$ & $-2,4126$ \\
\hline$D_{1}$ Variabel dummy lokasi dalam hamparan & $-0,0447^{\star}$ & $-2,1263$ \\
\hline $\mathrm{D}_{2}$ Variabel dummy lokasi terpencar & $-0,0016$ & $-0,0473$ \\
\hline \multicolumn{3}{|l|}{ Sigma-squared $\left(\sigma_{s}^{2}=\sigma_{v}^{2}+\sigma_{u}^{2}\right)$} \\
\hline $\operatorname{Gamma}\left(\gamma=\sigma_{u}^{2} / \sigma_{s}^{2}\right)$ & 0,8354 & 11,7104 \\
\hline
\end{tabular}


Sebagaimana yang diduga, faktor produksi yang pengaruhnya dominan adalah tingkat luasan areal keramba jaring apung, benih dan pakan ikan. Selain sangat nyata (significant), nilai koefisien parameternya pun paling besar (masing sebesar 0,4479, 0,2261dan 0,6253 ). Mengingat bentuk fungsi adalah Cobb-Douglass, maka nilai koefisien tersebut secara langsung mencerminkan elastisitasnya. Dengan demikian, penambahan $1 \%$ luas areal keramba jaring apung akan meningkatkan produksi ikan kerapu sebanyak $0,4 \%$; penambahan $1 \%$ benih ikan akan meningkatkan produksi ikan kerapu sebanyak $0,2 \%$; dan penambahan $1 \%$ pakan ikan akan meningkatkan produksi ikan kerapu sebanyak $0,6 \%$.

\section{Tingkat efisiensi teknis}

Rata-rata tingkat efisiensi teknis yang dicapai pembudidaya pembesaran ikan kerapu dalam keramba jaring apung di lokasi penelitian adalah sebesar 0,758. Artinya, rata-rata produktivitas yang dicapai adalah sebesar $76 \%$ dari frointer yakni produktivitas maksimum yang dapat dicapai dengan sistem pengelolaan yang terbaik (the best practiced). Secara umum sebenarnya tingkat efisiensi teknis tersebut relatif merata (yang ditunjukkan dengan koefisien variasi sebesar 0,164 ) dan tergolong dalam kategori tingkat efisiensi teknis sedang - tinggi.

Dalam Gambar 1 disajikan bentuk sebaran pembudidaya ikan menurut tingkat efisiensi teknis yang dicapainya. Tampak bahwa dari seluruh pembudidaya ikan yang diteliti, sebagian besar pembudidaya ikan $(51,4 \%)$ berada pada selang tingkat efisiensi teknis $0,6-0,8$. Proporsi pembudidaya ikan yang mendekati frointer (Tingkat Efisiensi Teknis mendekati 1,0) ada sebanyak $9 \%$, sedangkan yang berada di bawah 0,5 hanya $6 \%$.

Tingkat efisiensi teknis dapat diinterpretasikan berwajah ganda. Di satu sisi, tingkat efisiensi teknis yang tinggi mencerminkan prestasi pembudidaya ikan dalam keterampilan manajerial usaha budidaya pembesaran ikan kerapu dalam keramba jaring adalah cukup tinggi. Penguasaan informasi dan pengambilan

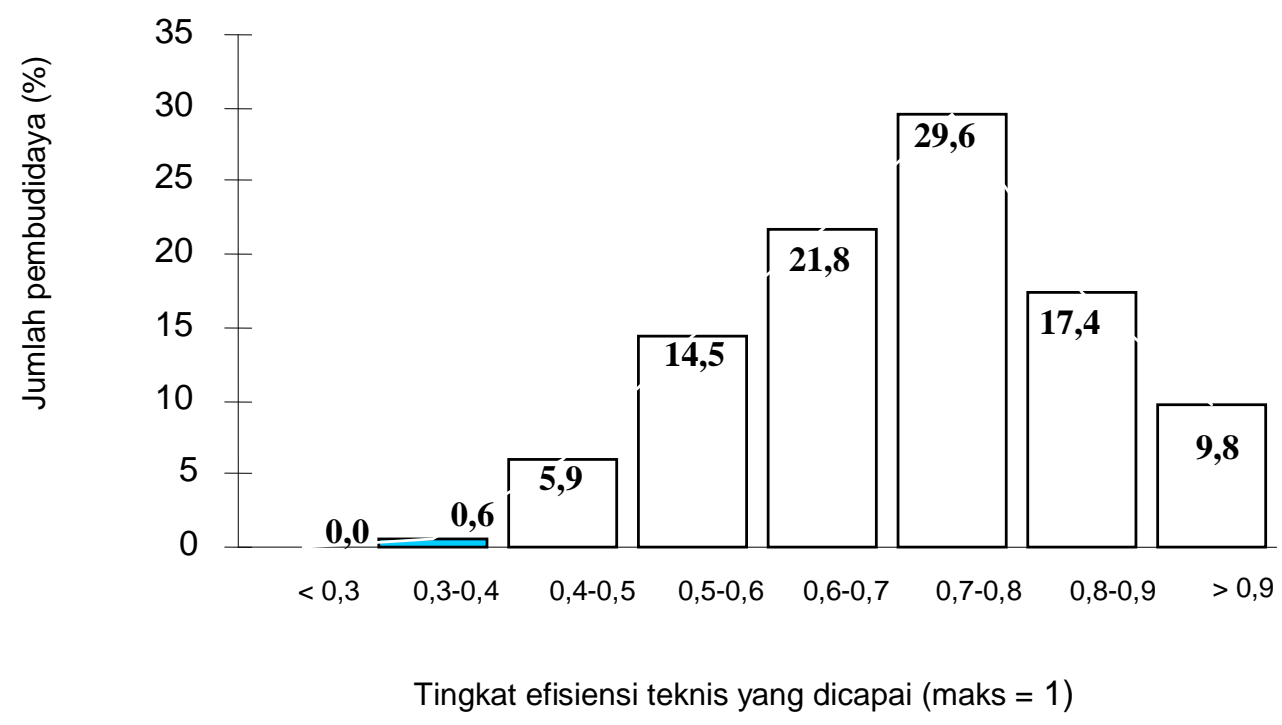

Gambar 1. Sebaran pembudidaya ikan menurut tingkat efisiensi teknis yang dicapai 
keputusan dalam mengelola faktor-faktor penting yang mempengaruhi kinerja produktivitas usaha budidayanya dapat dinilai berada dalam level yang memuaskan. Di sisi lain, tingkat efisiensi teknis yang tinggi juga merefleksikan bahwa peluang yang kecil untuk meningkatkan produktivitas yang cukup tinggi, karena senjang antara tingkat produktivitas yang telah dicapainya dengan tingkat produktivitas maksimum yang dapat dicapai dengan sistem pengelolaan terbaik (the best practiced) cukup sempit. Dengan kata lain, agar dapat meningkatkan produktivitas secara nyata maka dibutuhkan inovasi teknologi yang lebih maju. Sudah barang tentu hal ini tidak mudah karena memerlukan terobosan-terobosan teknologi yang lazimnya diharapkan dari aktivitas penelitian.

\section{Faktor-faktor yang mempengaruhi efisien- si teknis}

Pada fungsi "U" (Inefficiency Function) dari 7 variabel yang dihipotesiskan merupakan determinan inefisiensi terdapat tiga faktor yang pengaruhnya nyata (yaitu $z_{2}, z_{5}, z_{1}, z_{3}$ dan $D_{1}$ ). Selanjutnya jika peranan tiap faktor yang berpengaruh nyata dicerminkan oleh nilai koefisien parameter (semakin besar koefisiennya berarti semakin penting peranannya), maka faktor terpenting adalah $z_{2}$ (pangsa pendapatan dari usaha budidaya ikan kerapu terhadap total pendapatan keluarga). Urutan berikutnya adalah $z_{5}$ (pelatihan budidaya ikan kerapu, $z_{1}$ (pendapatan per kapita), $\quad z_{3}$ (umur pembudidaya ikan) dan variabel dummy lokasi keramba jaring apung dalam hamparan dekat pantai $\left(D_{1}\right)$.

Peranan usaha budidaya ikan kerapu bagi ekonomi keluarga pembudidaya ikan ternyata sangat menentukan tingkat efisiensi teknis usaha budidaya pembesaran ikan kerapu dalam keramba jaring apung. Semakin penting peranannya, yakni pangsa pendapatan dari usaha budidaya pembesaran ikan kerapu terhadap total pendapatan keluarga $\left(\mathrm{z}_{2}\right)$ yang semakin besar, maka semakin rendah ketidakefisienan yang terjadi (secara teknis semakin tidak efisien). Selain lebih tinggi peranannya, ternyata koefisien variasinya juga lebih rendah. Artinya, kelompok keluarga pembudidaya ikan yang mengandalkan nafkahnya dari usaha budidaya ikan kerapu bukan saja lebih efisien tetapi prestasi dalam kelompok ini juga lebih merata (Tabel 2.).

Peranan usaha budidaya ikan kerapu bagi ekonomi keluarga pembudidaya ikan ternyata sangat menentukan tingkat efisiensi teknis usaha budidaya pembesaran ikan kerapu dalam keramba jaring apung. Semakin penting peranannya, yakni pangsa pendapatan dari usaha budidaya pembesaran ikan kerapu terhadap total pendapatan keluarga $\left(\mathrm{z}_{2}\right)$ yang semakin besar, maka koefisien variabel pelatihan budidaya kerapu $\left(z_{5}\right)$ yang negatif merupakan indikasi bahwa tingkat efisiensi teknis yang lebih rendah pada umumnya terjadi di kalangan pembudidaya ikan yang kurang mengikuti pelatihan budidaya tersebut. Jika seringnya mengikuti pelatihan budidaya ikan

Tabel 2. Sebaran tingkat efisiensi teknis menurut kelompok pangsa pendapatan dari usaha budidaya pembesaran ikan kerapu dalam keramba jaring apung terhadap total pendapatan keluarga $\left(z_{2}\right)$

\begin{tabular}{ccc}
\hline $\begin{array}{c}\text { Pangsa pendapatan dari usaha budidaya ikan } \\
\text { kerapu terhadap pendapatan total }\end{array}$ & $\begin{array}{c}\text { Rata-rata } \\
\text { efisiensi teknis }\end{array}$ & $\begin{array}{c}\text { Koefisien } \\
\text { variasi }(\%)\end{array}$ \\
\hline$Z_{2} \leq 0.25$ & 0,66 & 21,18 \\
$0.25<\mathrm{Z}_{2} \leq 0.50$ & 0,71 & 18,33 \\
$0.50<\mathrm{Z}_{2} \leq 0.75$ & 0,73 & 16,84 \\
$\mathrm{Z}_{2}>0.75$ & 0,76 & 13,75 \\
\hline
\end{tabular}


kerapu berkorelasi dengan tingkat pengetahuan dan keterampilan tentang budidaya ikan kerapu yang dimiliki pembudidaya ikan maka ada kecenderungan telah terjadinya peningkatan dalam inovasi dalam berbudidaya ikan kerapu.

Dengan kata lain, para pembudidaya ikan yang lebih sering mengikuti pelatihan budidaya ikan kerapu cenderung lebih mampu melakukan antisipasi terhadap menurunnya kualitas sumberdaya air (kesuburan fisik dan kimia air di perairan sekitar areal budidaya), sehingga produktivitas yang dicapai lebih tinggi dari pada yang kurang sering atau bahkan tidak pernah mengikuti kegiatan pelatihan budidaya ikan kerapu. Pembudidaya ikan yang lebih sering mengikuti pelatihan budidaya ikan kerapu akan lebih banyak memperoleh informasi tentang budidaya tersebut dan cenderung lebih progresif.

Pendapatan per kapita $\left(z_{1}\right)$ berpengaruh positif terhadap efisiensi teknis (negatif terhadap inefisiensi teknis) usaha budidaya pembesaran ikan kerapu dalam keramba jaring apung. Mengingat bahwa pendapatan per kapita keluarga pembudidaya ikan umumnya berkorelasi positif dengan kemampuan pembudidaya ikan dalam menyediakan modal untuk usaha budidayanya. Fenomena tersebut merupakan bukti empiris bahwa meningkatnya kemampuan pembudidaya ikan dalam membiayai usaha budidaya sangat kondusif untuk meningkatkan efisiensi teknis usaha budidayanya. Dengan meningkatnya kemampuan permodalan maka makin mudah bagi pembudidaya ikan untuk memperoleh masukan (input) dengan mutu yang lebih baik dan tepat waktu.

Koefisien variabel umur pembudidaya ikan yang negatif merupakan indikasi bahwa tingkat efisiensi teknis yang lebih rendah pada umumnya terjadi pada kalangan pembudidaya ikan yang umurnya lebih muda. Jika umur pembudidaya ikan berkorelasi positif dengan pengalaman maka ada kecenderungan terjadi peningkatan dalam inovasi dan adopsi yang tinggi. Dengan kata lain, dibanding dengan pembudidaya ikan yang lebih muda ternyata pembudidaya ikan yang lebih tua lebih progresif dan mampu melakukan antisipasi terhadap menurunnya kualitas sumberdaya air (kesuburan fisik dan kimia air) dan meningkatnya serangan penyakit ikan kerapu sehingga produktivitas yang dicapai lebih tinggi daripada yang dicapai oleh pembudidaya ikan yang lebih muda dalam melakukan antisipasi terhadap perubahan tersebut. Hal ini selaras dengan pernyataan yang banyak disampaikan oleh pembudidaya ikan (85\%) bahwa adanya kecenderungan angkatan kerja usia muda semakin tidak tertarik untuk menjadi pembudidaya ikan. Para pembudidaya ikan tersebut menyatakan bahwa angkatan kerja usia muda umumnya cenderung lebih tertarik untuk bekerja di bidang lainnya (sektor non perikanan).

Koefisien variabel dummy lokasi keramba jaring apung dalam hamparan dekat pantai $\left(D_{1}\right)$ berpengaruh positif terhadap efisiensi teknis (negatif terhadap inefisiensi teknis) menunjukkan bahwa penggunaan sistem hamparan dapat meningkatkan efisiensi teknis budidaya ikan kerapu dalam jaring apung. Hal ini membuktikan pula bahwa upaya peningkatan efisiensi teknis akan kurang efektif jika dilakukan secara individual karena akan terkait dengan adanya interdependensi, terutama dalam aspek pengelolaan kualitas air, penanggulangan penyakit ikan dan struktur pasar.

\section{Kesimpulan dan Saran}

\section{Kesimpulan}

Rata-rata tingkat efisiensi teknis yang dicapai para pembudidaya ikan kerapu dalam keramba jaring apung adalah sebesar 0,76 dan relatif merata (koefisien variasi sebesar 0,18). Proporsi pembudidaya ikan kerapu yang efisiensi teknisnya kurang dari 0,6 hanya sebanyak $21 \%$ sehingga sebarannya cenderung terkonsentrasi pada selang efisiensi teknis sebesar 0,6 - 0,8 (seba- 
nyak $51,4 \%$ ). Secara umum tingkat efisiensi teknis yang dicapai oleh usaha budidaya pembesaran ikan kerapu dalam keramba jaring apung di Perairan Teluk Lampung tergolong dalam kategori sedang - tinggi. Proporsi pembudidaya ikan pada level efisiensi teknis yang tinggi $(0,7-0,8)$ lebih banyak $(29,60 \%)$ dibanding dengan pembudidaya ikan pada level efisiensi teknis sedang $(0,6-0,7)$ yaitu sebanyak $21,8 \%$.

Determinasi faktor utama yang mempengaruhi inefficiency adalah tingkat pangsa pendapatan keluarga dari usaha bidudaya ikan terhadap total pendapatan keluarga. Tingkat efisiensi teknis yang lebih tinggi dicapai oleh para pembudidaya ikan kerapu yang sebagian besar pendapatannya berasal dari usaha budidaya ikan kerapu dalam keramba jaring apung. Faktor lain yang terbukti kondusif adalah pelatihan budidaya ikan kerapu yang lebih sering diikuti oleh pembudidaya, pendapatan total perkapita yang lebih tinggi, umur pembudidaya ikan dan variabel dummy lokasi keramba jaring apung dalam hamparan dekat pantai.

\section{Saran}

Berkenaan dengan upaya peningkatan efisiensi dan produksi dari hasil budidaya pembesaran ikan kerapu dalam keramba jaring apung di Propinsi Lampung, dan mengingat bahwa efisiensi teknis yang dicapai oleh usaha budidaya pembesaran ikan kerapu dalam keramba jaring apung berada pada level sedang - tinggi (0,6 $0,8)$ dengan kecenderungan pada level efisiensi teknis yang tinggi atau mendekati frointer $(0,7-0,8)$, maka strategi kebijakan pengembangan budidaya ikan kerapu hendaknya dilakukan dengan pendekatan ekstensifikasi melalui peningkatan perluasan areal keramba jaring apung. Hal ini didukung oleh kondisi lapang yang menunjukkan bahwa tingkat pemanfaatan areal usaha budidaya ikan kerapu di Propinsi Lampung baru mencapai $0,52 \%$ dari total potensi luasan areal usaha untuk budidaya ikan kerapu dalam keramba jaring apung. Selain itu secara statistik, didukung pula oleh adanya pengaruh nyata dari variabel dummy lokasi keramba jaring apung dalam hamparan dekat pantai $\left(D_{1}\right)$, maka kebijakan peningkatan efisiensi teknis dalam budidaya ikan kerapu tersebut perlu pula mempertimbangkan hal-hal yang mendorong konsolidasi usaha budidaya pembesaran ikan kerapu dalam keramba jaring apung yang berbasiskan hamparan.

Mengacu pada karakteristik usaha budidaya pembesaran ikan kerapu dalam keramba jaring apung, pendekatan pengembangan sistem budidaya sedapat mungkin diarahkan pada cara-cara mengintegrasikan pengelolaan antar usaha budidaya ikan kerapu dalam suatu sistem yang bersinergi dan mencakup suatu wilayah hamparan keramba jaring apung. Hal ini disebabkan oleh adanya faktor interdependesi, terutama dalam aspek pengelolaan kualitas air dan penanggulangan penyakit ikan kerapu. Dalam pengelolaan kualitas air, interdependensi antar pembudidaya ikan merupakan konsekuensi logis dari rancang bangun penentuan kawasan perairan areal budidaya ikan kerapu. Dalam penanggulangan penyakit ikan kerapu, interdepensi antar pembudidaya ikan kerapu merupakan implikasi logis dari karakteristik ekosistem.

Pentingnya pengembangan budidaya ikan kerapu berbasis sistem hamparan terkait pula dengan adanya struktur pasar ikan kerapu yang oligopolistik. Adanya fenomena kondisi struktur pasar ikan kerapu yang cenderung oligopolistik atau monopolistik terselubung (pseudo monopolistic) sehingga menempatkan pembudidaya ikan berada pada posisi tawar menawar (bargaining position) yang lemah dan cenderung menjadi sebagai penerima harga (price takers) (Manadiyanto, et al., 2004), bila kondisi pasar tersebut disikapi secara kolektif oleh pembudidaya ikan sehamparan akan terjadi suatu sinergi yang dapat memberikan perubahan yang lebih positif dan nilai tambah terhadap usaha budidayanya. 
Mengingat bahwa secara rata-rata tingkat efisiensi teknis yang dicapai oleh para pembudidaya ikan kerapu telah cukup tinggi dan didukung oleh kenyataan dari hasil pengujian secara statistik bahwa tingkat pangsa pendapatan keluarga dari usaha bidudaya ikan merupakan determinan faktor utama yang mempengaruhi kondisi efisiensi teknis usaha budidayanya, maka pada tahap implementasi upaya pengembangan budidaya pembesaran ikan kerapu dalam keramba jaring apung dengan pendekatan ekstensifikasi yang berbasiskan hamparan akan efektif jika dalam upaya pengembangan budidaya tersebut benar-benar bersifat inovatif dan imperatif, terutama berkaitan dengan kegiatan penerapan teknologi baru oleh pembudidaya ikan.

\section{Daftar Pustaka}

Aigner, D.J., C.A.K. Lovell, and F.Schmid. 1977. Formulation and estimation of stochastic frointer production models. J. Econometrics. 6 : 21-37.

Akbar, S. 2001. Pembesaran ikan kerapu bebek dan kerapu macan di keramba jaring apung.Prosiding Lokakarya Nasional Pengembangan Agribisnis Kerapu Bebek. Ristek DKP dan BPPT. Jakarta. Hal 141-148

Battase, G.E. and T.J. Coelli. 1988. Prediction of firm-level technical efficiencies with a generalised frointer production and panel data. J. Econometrics. 38:387399.

Battase, G.E. and T.J. Coelli. 1992. Frointer production functions. technical efficiency and panel data: with application to paddy farmers in India. J. Production Analysis. 3: 153-169.

Battase. G.E. and T.J. Coelli. 1995. A model for technical inefficiency effects in a stochastic frointer production function for panel data. Empirical Econometrics. 20: 325332.

Coelli. T.J. 1996. A guide to frointer version 4.1: a computer program for stochastic frointer production and cost function estimation. Centre for Efficiency and Productivity Analysis. University of New England - Armidale. New South Wales.

Erwidodo. 1992. Stochastic production frointer and panel data: measuring economic efficiency on wetland rice farms in West Java. J. Agro-Ekonomi. 11 (1): 19-36.

Greene, W.H. 1982. Maximum likelihood estimation of stochastic frointer production models. J. Econometrics. 18: 285-289.

Jondrow. J., C. A. K Lovell, I. S. Materov, and P. Schmid. 1982. On estimation of technical inefficiency in the stochastic frointer production function model. J. Econometrics. 19: 233-236.

Kumbhakar, S.C. 1987. The specification of technical and allocative inefficiency in stochastic production and profit frointers. J. Econometrics. 34: 335-348.

Manadiyanto, Z. Nasution, S. A. Pranowo. dan Tajerin. 2002. Pengembangan model pusat bisnis ikan kerapu di Batam. Riau. Laporan teknis. Pusat Riset Pengolahan Produk dan Sosial Ekonomi Kelautan dan Perikanan. Jakarta. $152 p$.

Meeusen, W. and J.V.D. Broeck. 1977. Efficiency estimation from cobbdouglas production functions with composed error. International Economic Review. 18: 435-444. 
Jurnal Perikanan (J. Fish. Sci.) VI (2) : 45-55 ISSN : 0853-6384

Siregar, M. 1987. Effects of some selected variables on rice-farmers technical efficiency. J. Agro-Ekonomi, 6 (1): 94-102.

Waldman, D.M. 1984. Properties of technical efficiency estimators in the stochastic frointer model. J. Econometrics. 25: 353-354.

Yao, S. and Z. Liu. 1998. Determinants of grain production and technical efficiency in China. J. Agricultural Economics. 49 (2): 171-184 